\title{
The International Geological Congress at Madrid.
}

THE fourteenth session of the International Geological Congress was held in Madrid towards the end of May last. It was presided over by Señor D. César Rubio y Muñoz, under the honorary presidency of His Majesty King Alfonso. Señor Rubio is the President of the Board of Mines and was formerly President of the Geological Institute, entrusted with the preparation of the geological map of Spain. His successor, Señor D. Domingo de Orneta, who was to have taken an active part in the meeting, died shortly before it was held.

The Geological Congress is almost the sole survivor of the scientific congresses which formerly played such an important rôle in international scientific comity. It is still open to men of science of all nations, a distinction to which the scientific unions constituted under the International Research Council can lay no claim.

After a preliminary meeting of the Government delegates on the previous day, the congress was formally inaugurated by the King on Monday, May 24. The total number of members was more than a thousand. Many of these had already taken part in excursions to the Canary Islands and Morocco, or to Huelva, famous for its cupriferous pyrites, or other places of geological interest in the south of Spain. Toledo, Aranjuez, Almaden with its mines of mercury, and the Guadarrama mountains that separate old from New Castile were visited during the meeting, and afterwards there were other excursions to the Balearic Islands, the potash deposits in Catalonia, the Pyrenees, the important coalfield of Asturias, and the iron ores in the neighbourhood of Bilbao.

The Spanish Government and the municipalities of Madrid and of the towns that were visited in the excursions extended splendid hospitality to the members of the Congress. There was a Royal reception at the Palace, a gala theatrical performance, a municipal garden party, and a banquet at which the speeches, twenty-seven in number, commenced with the fish course. This was followed by a charming exhibition of national costumes, dances, and singing, in which the performers were all amateurs.

In spite of these attractions, time was found in the different sections of the Congress for valuable discussions on matters of current geological interest.

There were a number of contributions on recent physical methods of studying the configuration and economic possibilities of the rocks of particular areas by electric, magnetic, and gravimetric methods, and observation of the propagation in the earth's crust of artificially produced vibrations.
The pyritic deposits of the south of Spain, to which reference has already been made, were the subject of important papers, and the greater part of two days was devoted to the discussion of the question as to whether they were formed by replacement or owed their origin to magmatic or pneumatolytic intrusion or deposition. Considerable attention was also given to the part played by Hercynian and Alpine movements in mountain building, more especially in Spain.

Perhaps, however, what was of the greatest interest to the British representatives was the consideration of questions of African geology in connexion with the proposed international geological map of Africa on a scale of one in five million, which was resolved on at the previous Congress at Brussels in 1922. A number of representatives of British African surveys were present as well as those of France, Belgium, Spain, Portugal, Italy, and Egypt. It was gratifying to note the progress that has been made in the interval. A geological map of the whole of South Africa has been recently published on a scale of one in one million, and one of Egypt on a scale of one in two million, and of South-West Africa on the same scale. Maps of the Anglo-Egyptian Sudan and Somaliland on a scale of one in three million, of the Gold Coast on one in one million five hundred thousand, and Gambia on one in five hundred thousand, and of all the remaining British African colonies or mandated territories, Nigeria, Uganda, Kenya, Tanganyika, Nyasaland, British Bechaanaland, and Northern Rhodesia, as well as of Southern Rhodesia, on a scale of one in two million, have been prepared, and work on other parts of Africa is well advanced. The map of the whole of Africa on the scale of one in five million will be prepared under the auspices of the Belgian Government as soon as all the materials are ready.

Of permanent value as a conspectus of the geology of Spain are the excellent guides, some nineteen in number, to the excursions. Many of them are published not only in Spanish but also in French, English, or German, or more than one of these languages. At the same time the Municipality of Madrid presented the members of the Congress with a wellillustrated volume on the Quaternary rocks of the Manzanares Valley by José Péres de Barradas.

The greatest achievement of the Congress, however, was the re-creation among geologists from all parts of the world of the atmosphere of friendliness and cordiality that prevailed in the days, which now seem so remote, "before the War."

\section{Cancer Causation: Importance of Cell Physiology.}

$\mathrm{I}$ an interesting paper read before the German 1 Chemical Society, at the meeting recently held at Kiel, Dr. Otto Warburg said that the attempts made artificially to produce carcinoma by tar-painting or by X-ray radiation showed that the normal tissues contain cells in. which carcinoma may begin without help from any outside cells or micro-organisms. There is no cancer bacillus, just as there is no diabetes or arteriosclerosis bacillus. The cancer problem is a problem of cell physiology in the narrow sense, and limited to the physiology of the body cells.

Since cancerous tissue grows differently from normal tissue, that is to say, irregularly and to excess, it follows that the metabolism of the cancer cell differs from that of the normal cell. Since, on the other hand, the carcinoma cell as an actual body cell originates from normal cells, it becomes necessary to correlate carcinoma metabolism with normal metabolism. Like normal organs, the tumour consumes oxygen and gives off carbon dioxide; the veins of the tumour contain less oxygen and more carbon dioxide than the arteries. Like normal organs the tumour requires glucose, and its veins contain less glucose than the arteries. But, unlike the normal organs, the tumour produces lactic acid which is passed into the blood, a portion of this acid being obtained from the blood sugar, which the tumour to a certain extent oxidises in the same way as normal organs, but for the most part splits into lactic acid. Careful research has shown that there is lactic fermentation of the glucose, and in fact there are a large number of different kinds of malignant tumours, for example, transplanted rat 